\title{
Investigating suspended sediment dynamics in contrasting agricultural catchments using ex situ turbidity-based suspended sediment monitoring
}

\author{
S. C. Sherriff ${ }^{1,2}$, J. S. Rowan ${ }^{2}$, A. R. Melland ${ }^{3}$, P. Jordan ${ }^{4,5}$, O. Fenton ${ }^{1}$, and D. Ó hUallacháin ${ }^{1}$ \\ ${ }^{1}$ Johnstown Castle Research Centre, Teagasc, Wexford, Ireland \\ ${ }^{2}$ School of the Environment, University of Dundee, Dundee, DD1 4HN, Scotland, UK \\ ${ }^{3}$ National Centre for Engineering in Agriculture, University of Southern Queensland, Toowoomba, Australia \\ ${ }^{4}$ School of Environmental Sciences, Ulster University, Coleraine, Co. Derry, BT52 1SA, UK \\ ${ }^{5}$ Agricultural Catchments Programme, Johnstown Castle Research Centre, Teagasc, Wexford, Ireland
}

Correspondence to: S. C. Sherriff (sophie.sherriff@teagasc.ie)

Received: 12 February 2015 - Published in Hydrol. Earth Syst. Sci. Discuss.: 3 March 2015

Revised: 6 July 2015 - Accepted: 9 July 2015 - Published: 3 August 2015

\begin{abstract}
Soil erosion and suspended sediment (SS) pose risks to chemical and ecological water quality. Agricultural activities may accelerate erosional fluxes from bare, poached or compacted soils, and enhance connectivity through modified channels and artificial drainage networks. Storm-event fluxes dominate SS transport in agricultural catchments; therefore, high temporal-resolution monitoring approaches are required, but can be expensive and technically challenging. Here, the performance of in situ turbidity sensors, conventionally installed submerged at the river bankside, is compared with installations where river water is delivered to sensors ex situ, i.e. within instrument kiosks on the riverbank, at two experimental catchments (Grassland B and Arable B). The in situ and ex situ installations gave comparable results when calibrated against storm-period, depth-integrated SS data, with total loads at Grassland B estimated at 12800 and $15400 \mathrm{t}$, and 22600 and $24900 \mathrm{t}$ at Arable B, respectively. The absence of spurious turbidity readings relating to bankside debris around the in situ sensor and its greater security make the ex situ sensor more robust. The ex situ approach was then used to characterise SS dynamics and fluxes in five intensively managed agricultural catchments in Ireland which feature a range of landscape characteristics and land use pressures. Average annual suspended sediment concentration (SSC) was below the Freshwater Fish Directive (78/659/EEC) guideline of $25 \mathrm{mg} \mathrm{L}^{-1}$, and the continuous hourly record demonstrated that exceedance occurred
\end{abstract}

less than $12 \%$ of the observation year. Soil drainage class and proportion of arable land were key controls determining flux rates, but all catchments reported a high degree of inter-annual variability associated with variable precipitation patterns compared to the long-term average. Poorly drained soils had greater sensitivity to runoff and soil erosion, particularly in catchments with periods of bare soils. Well drained soils were less sensitive to erosion even on arable land; however, under extreme rainfall conditions, all bare soils remain a high sediment loss risk. Analysis of storm-period and seasonal dynamics (over the long term) using high-resolution monitoring would be beneficial to further explore the impact of landscape, climate and land use characteristics on SS export.

\section{Introduction}

Excessive supply of fine sediments $(<125 \mu \mathrm{m})$ and sedimentassociated pollutants are detrimental to aquatic ecosystems (Wood and Armitage, 1997; Collins et al., 2011; Kemp et al., 2011). Elevated suspended sediment (SS) concentrations decrease light penetration and can reduce primary productivity. Deposition of sediments onto river channel beds also degrades habitat quality for benthic species and spawning fish (Bilotta and Brazier, 2008). In the European Union, the Water Framework Directive (WFD - OJEU, 2000) requires that 
water quality meet a "good" standard, but no binding environmental standards yet exist for SS across member states (Brils, 2008; Collins and Anthony, 2008). In rivers, the EU Freshwater Fish Directive (FFD - OJEU, 2006) introduced a mean annual threshold of $25 \mathrm{mg} \mathrm{L}^{-1}$, but this was subsequently repealed. Phosphorus (P) targets are, however, binding and because of its strong affinity for particulate transport, catchment sediment fluxes are an essential area of research.

Agriculture is commonly linked with elevated rates of soil erosion (Foster et al., 2011; Glendell and Brazier, 2014), but the degree to which sediment exports from catchments can be attributed to specific land-management practices is challenging to measure (Rowan et al., 2012). Catchments exhibit complex responses to different land uses, (e.g. arable or grazing practices) which are further influenced by climate, landscape setting and topographic controls (Wass and Leeks, 1999). A comprehensive evaluation of the extent of erosion and elevated sediment supply, therefore, requires a robust determination of sediment flux (Navratil et al., 2011), knowledge of the sources and fate of fine sediments within the system (Walling, 2005), and an appreciation of the risks that elevated concentrations present to aquatic ecosystems (Bilotta and Brazier, 2008). This evidence base can be used to better inform integrated land, water and sediment management strategies.

Sediment losses from agricultural areas are commonly attributed to arable practices (Walling et al., 1999; Wass and Leeks, 1999; Freebairn et al., 2009; Van Oost et al., 2009; Duvert et al., 2010), especially where bare or freshly tilled soils are exposed to rainfall-runoff processes (Regan et al., 2012). Arable farming typically involves the mechanical redistribution of soil through ploughing and seed bed preparation, and via erosion from compacted and/or bare fields and down-slope tramlines (Chambers and Garwood, 2000; Withers et al., 2006; Boardman et al., 2009; Silgram et al., 2010; Regan et al., 2012; Soane et al., 2012). Over-grazed grassland soils are also an important sediment source (Bilotta et al., 2010) and critical to the transport of particle-bound pollutants, such as P (Haygarth et al., 2006). Poaching of soils by livestock, particularly cattle wintered outside, results in loss of soil structure and compaction around gates, drinking troughs and, where access is not restricted, channel banks (Trimble and Mendel, 1995; Evans et al., 2006).

Erosion risk is conditioned by physical catchment characteristics (soil type and hydrology), and erodibility determined by physiography (slope length, steepness and shape, ground cover and soil management). Soil drainage class, for example, is dictated by landscape position whereby well drained soils, such as Brown Earths and Podzols commonly located on hillslopes, contribute sediment predominantly through sub-surface pathways such as relocation of fine surface sediments vertically and/or horizontally through the soil profile, and preferential flow through macropores (Chapman et al., 2001; Deasy et al., 2009). Conversely, poorly drained soils, such as Gleys (surface and groundwater) and silt and clay dominated alluvial soils in proximity to watercourses, are at greater risk of overland-flow generation and surface soil erosion due to reduced infiltration capacity. The installation of surface and sub-surface drains can also alter natural flow pathways (Ibrahim et al., 2013). Drainage installation and maintenance, for example, can result in faster quick-flow, resulting in an increased likelihood of more frequent, higher magnitude and short duration sediment transfers associated with storm runoff (Wiskow and van der Ploeg, 2003; Deasy et al., 2009; Florsheim et al., 2011).

To accurately quantify sediment fluxes from complex catchments, field monitoring programmes require three considerations. Firstly, robust flow and suspended sediment concentration (SSC) data capable of accurately describing shortterm fluxes (Navratil et al., 2011). Secondly, the duration of the measurements must be sufficiently long to be "representative" of either stationary long-term averages (inclusive of natural variability), or to reveal temporal trends of increasing or decreasing loads or concentrations. Capturing crucial high-magnitude, low-frequency events is, therefore, vital to generating meaningful flux determinations (Walling and Webb, 1988; Wass and Leeks, 1999). Thirdly, monitoring programmes need to be operationally cost-effective.

Sediment load estimation based on SSC-discharge rating curves has been widely superseded by catchment outlet and near-continuous turbidity monitoring (Lewis, 2003; Jarstram et al., 2010; Melland et al., 2012a). The latter requires turbidity sensors, loggers and infrastructure that cope with issues such as debris interference, bio-fouling, power outages and equipment/data security (Wass and Leeks, 1999; Jordan et al., 2007; Owen et al., 2012). Assessment of new monitoring strategies, compared to traditional in situ turbidity-SSC monitoring programmes, is essential to assess improvements and limitations, and to validate their implementation.

There have been relatively few sediment flux investigations in Ireland (Melland et al., 2012a; Harrington and Harrington, 2013; Thompson et al., 2014). Initially regulated and managed through the Nitrates Directive (OJEU, 1991, 2007), the transfer of diffuse agricultural pollutants across the EU is now primarily integrated into obligations under the WFD. In Ireland, soil conservation issues also fall under the Nitrates Directive regulations, but the impact of SS in rivers is commonly compared to the repealed FFD target due to the absence of explicit sediment targets within the WFD.

As part of an experiment to evaluate the Nitrates Directive in Ireland, a common experimental design across six agricultural catchments included high temporal-resolution measurements of river nutrient and sediment exports (Wall et al., 2011). Using these catchments and data, the aims of this study were (1) to assess the efficacy of a novel ex situ SS monitoring technique in two catchments and (2) to investigate annual average sediment concentrations and loads in relation to soil drainage class and land use in five monitored catchments. One catchment situated in low-relief karst terrain was omitted from this study due to intermittent runoff 
combined with very low SS concentrations (cf. Mellander et al., 2012).

\section{Study location}

Suspended sediment monitoring was conducted in five catchments (Table 1) across Ireland (Fig. 1). Catchments were selected to represent the main intensive agricultural land use types in Ireland and dominant hydrological pathways (surface or sub-surface) at a scale where headwater to channel hydrological process were detectable (Fealy et al., 2010). The characteristics of individual catchments are summarised as follows.

Grassland A catchment $\left(7.9 \mathrm{~km}^{2}\right)$ is located in southwestern Ireland $\left(51^{\circ} 38^{\prime} \mathrm{N}, 8^{\circ} 47^{\prime} \mathrm{W}\right)$. Catchment soils are predominantly shallow well drained Brown Earths and Podzols with loam dominating the texture of A- and B-horizons, and smaller areas of Surface Water Gleys at the base of hillslopes. A coarse loamy drift with siliceous stone subsoil is underlain by Devonian old red sandstones and mudstones from the Toe Head and Castlehaven formations (Sleeman and Pracht, 1995), which form an unconfined productive aquifer (Mellander et al., 2014). Sub-surface water pathways are therefore dominant. Land is predominantly grazed by cattle for intensive dairy production and smaller areas of beef production with an average catchment stocking rate of 1.98 livestock units (LU) $\mathrm{ha}^{-1}$; additionally, minor areas of arable land use are present (Table 1).

Grassland B catchment $\left(11.0 \mathrm{~km}^{2}\right)$ is located in southeastern Ireland $\left(52^{\circ} 36^{\prime} \mathrm{N}, 6^{\circ} 20^{\prime} \mathrm{W}\right)$. Soil type is predominantly poorly drained Groundwater Gleys in the catchment lowlands with a clay loam texture in A- and B-horizons resulting from a clayey calcareous Irish Sea till subsoil. The uplands contain smaller areas of well drained Brown Earths; these soils are underlain by drift deposits with siliceous stones. The underlying geology is permeable, dominated by Ordovician volcanics and metasediments of the Campile formation (Tietzsch-Tyler et al., 1994), which form a productive aquifer with faults (Mellander et al., 2012). Artificial drainage is a key feature including open drains, defined here as ditches, and closed, sub-surface piped drains (predominantly $80 \mathrm{~mm}$ diameter). Grassland $\mathrm{B}$ is considered to be dominated by overland flow pathways (Mellander et al., 2012; Shore et al., 2013) except for areas of well drained soils featuring sub-surface transport pathways. Land is predominantly grass-based for dairy and beef cattle grazing, and also sheep enterprises (Shore et al., 2013) with a stocking rate of $1.04 \mathrm{LU} \mathrm{ha}^{-1}$. Arable crops such as spring barley are common on the well drained soils which are unmanaged between harvest and ploughing for the following crop.

Grassland C catchment $\left(3.3 \mathrm{~km}^{2}\right)$ is located in northeastern Ireland $\left(54^{\circ} 01^{\prime} \mathrm{N}, 6^{\circ} 51^{\prime} \mathrm{W}\right)$. Soils are mainly deep and moderately to poorly drained, characterised by a loam A-horizon texture and clay loam B-horizon and areas of shal- low well drained soils in the upper catchment areas underlain predominately by Lower Palaeozoic shale tills. The geology is Silurian metasediments and volcanics of the Shercock Formation (Geraghty et al., 1997), which create an unproductive aquifer. Overland flow and near-surface pathways are, therefore, dominant here. Land use is principally grass based for dairy cattle, sheep and beef cattle grazing (stocking rate 1.00 $\mathrm{LU} \mathrm{ha}^{-1}$ ).

Arable A catchment $\left(11.2 \mathrm{~km}^{2}\right)$ is located in south-eastern Ireland $\left(52^{\circ} 34^{\prime} \mathrm{N}, 6^{\circ} 36^{\prime} \mathrm{W}\right)$. Soils are predominantly shallow well drained Brown Earths with loam texture dominating the A- and B-horizons, and limited areas of poorly drained groundwater Gleys around the stream corridor to the east of the catchment (Melland et al., 2012a). Subsoils predominantly comprise fine loamy drift with siliceous stones over slate and silt stones of the Oaklands Formation (Tietzsch-Tyler et al., 1994), which produces a poorly productive aquifer. The well drained soils result in belowground hydrological transfers, particularly bedrock fissure flow (Mellander et al., 2012). Artificial drainage is limited to the poorly drained soil areas and comprises open ditches and sub-surface piped drainage. Land use is dominated by spring barley (land is unmanaged between cropping cycles and crop rotation is limited) with areas of permanent grassland for beef cattle and sheep grazing in more poorly drained areas (Melland et al., 2012a) at 0.40 $\mathrm{LU} \mathrm{ha}^{-1}$.

Arable B catchment $\left(9.5 \mathrm{~km}^{2}\right)$ is located in north-eastern Ireland $\left(53^{\circ} 49^{\prime} \mathrm{N}, 6^{\circ} 27^{\prime} \mathrm{W}\right)$. The soil type is a complex pattern of poorly to moderately drained soils (Melland et al., 2012a). Loam soil texture dominates the A-horizon and clay loams are dominant in the B-horizon. Subsoil is dominated by fine till containing siliceous stones with fluvioglacial sediments located near-channel. Soils are underlain by calcareous greywacke and banded mudstone geology (McConnell et al., 2001) and produce a poorly productive aquifer (Mellander et al., 2012). Hydrologically, surface pathways dominate; however, below-ground pathways may also be important, especially during winter (Melland et al., 2012a; Mellander et al., 2012). Artificial drainage is dominant, particularly in the poorly drained catchment areas. Arable land is dominated by winter-sown cereals, but also comprises maize and potatoes. These areas are unmanaged between cropping cycles; however, crop rotation is more common than at Arable A due to the wider range of crop types. Additional areas of permanent grassland are utilised for dairy cattle, beef cattle, and sheep grazing $\left(0.77 \mathrm{LU} \mathrm{ha}^{-1}\right)$.

\section{Materials and methods}

\subsection{Suspended sediment monitoring}

Monitoring for SS at catchment outlets was initiated in 2009 for Grassland B, Arable A and Arable B catchments and 2010 for Grassland A and Grassland C catchments. All catch- 


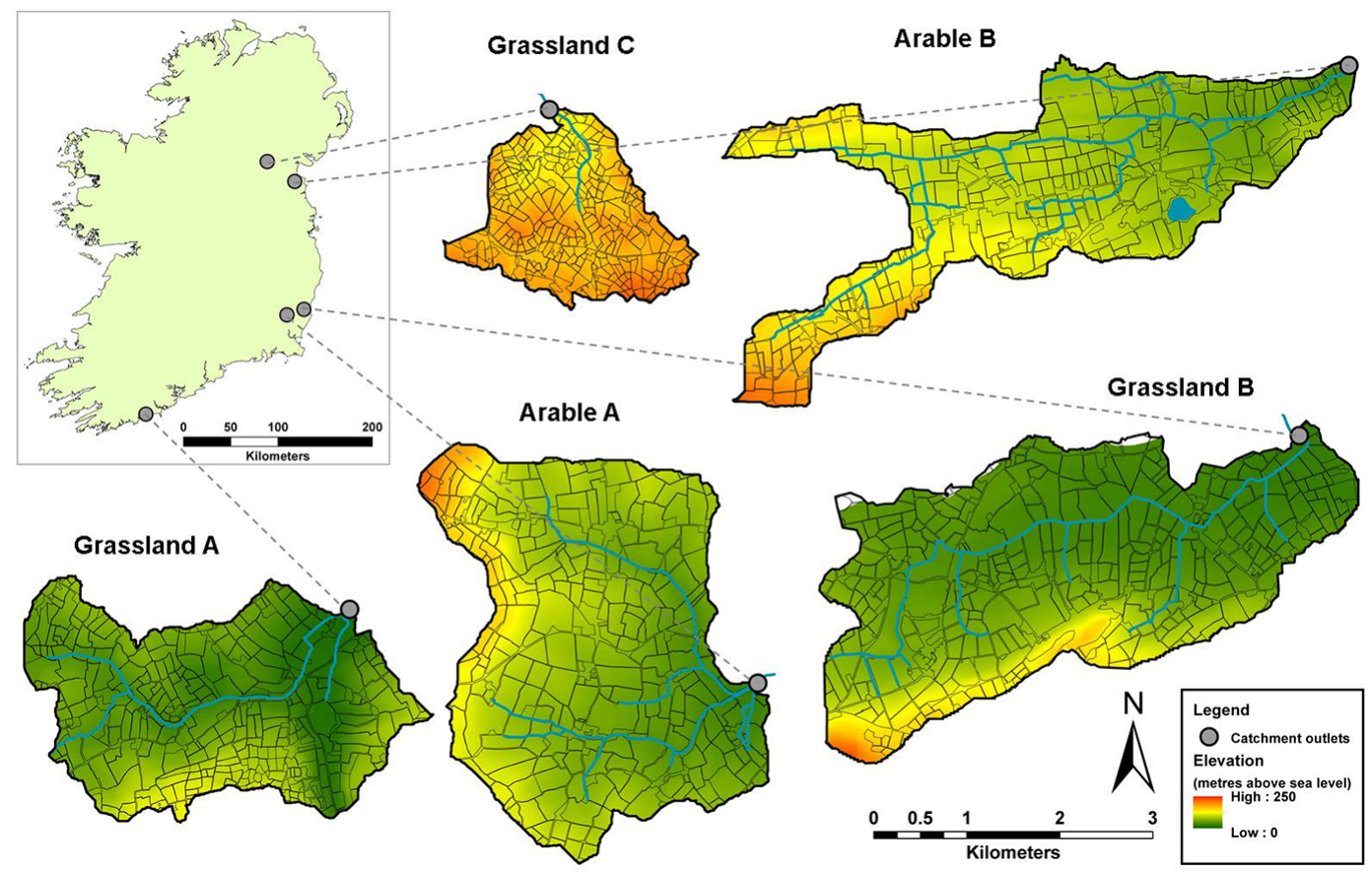

Figure 1. Map of catchment monitoring locations and study catchments with topographic and field size information.

ments had identical instrumentation deployed for temporally high-resolution nutrient, conductivity, temperature and turbidity data capture using bankside analysers mains powered at $230 \mathrm{~V}$ (Fig. 2; Wall et al., 2011; Jordan et al., 2012; Melland et al., 2012b). Turbidity (T) data were collected using a turbidity sensor (Solitax, Hach-Lange, Germany; range 0-4000 NTU; factory calibrated to 1000 NTU) and SC1000 controller at $10 \mathrm{~min}$ intervals. The sensors were located outof-stream (ex situ) in a rapidly and continuously circulating header tank with river water delivered from the channel by an in-stream pump $\left(30 \mathrm{~m}^{3} \mathrm{~h}^{-1}\right)$ located on the channel bed. The instrument tank was assumed well mixed as no particulate deposition occurred. Turbidity probes were fitted with wipers to prevent biological fouling, and checked monthly against deionised water (0 NTU) and a 20 NTU Formazin turbidity standard. Synchronised discharge data $\left(\mathrm{Q}-\mathrm{m}^{3} \mathrm{~s}^{-1}\right)$ were calculated from vented pressure-transducer stage measurements (OTT Orpheus-mini; OTT Germany). Stage height was converted to $\mathrm{Q}$ using velocity-area measurements (OTT Acoustic Doppler Current meter; OTT Germany) collected over non-standard flat-v weirs (custom made, Corbett Concrete, Ireland) and WISKI-SKED software (Grassland A, $R^{2}=0.96, n=272$; Grassland $\mathrm{B}, R^{2}=1, n=166$ (Mellander et al., 2015); Grassland C, $R^{2}=0.95$ and 0.97, $n=316$; Arable A, $R^{2}=1, n=376$ (Mellander et al., 2015); Arable $\mathrm{B}, R^{2}=0.94$ and $\left.1, n=493\right)$. Both Grassland $\mathrm{C}$ and Arable $\mathrm{B}$ had changing controls at higher discharges and WISKISKED provided two parts to the curves with two $R^{2}$ coefficients.
Turbidity units (NTU) were field-calibrated to SSC $\left(\mathrm{mg} \mathrm{L}^{-1}\right)$ using a combination of regular low-flow samples (at least fortnightly since programme initiation) and intensive sampling during high magnitude flow events with elevated SSCs. In all cases, water samples were collected from the instrument tank either manually, or using a programmable automatic water sampler (ISCO 6712; ISCO Inc. USA) with a $1 \mathrm{~m}$ pumping tube (pump capacity $\sim 0.9 \mathrm{~m} \mathrm{~s}^{-1}$ ) at predefined intervals of 30 or $60 \mathrm{~min}$ according to the specific storm characteristics. High SSC data capture was further targeted in Grassland B and Arable B using a turbidity-stratified sampling programme, whereby collection of $1000 \mathrm{~mL}$ samples was triggered when $\mathrm{T}$ measurements were within threshold turbidity bands of 140 to $160 \mathrm{NTU}, 240$ to $260 \mathrm{NTU}, 480$ to 530 NTU and 700 to 800 NTU. This circumvented the need to pre-set water samplers according to forecasted event characteristics. Water samples were stored at $4{ }^{\circ} \mathrm{C}$ on return to the laboratory before a sub-sample (minimum $100 \mathrm{~mL}$ ) was processed for SSC. Whatman GF/C glass-fibre filter papers $(1.2 \mu \mathrm{m})$ were pre-dried at $105^{\circ} \mathrm{C}$ for $1 \mathrm{~h}$, cooled in a desiccator and weighed before being used for vacuum filtration. Sediment concentrations were calculated from the weight of residue retained on the filter post-filtration once dried $>12 \mathrm{~h}$ at $105^{\circ} \mathrm{C}$ and cooled in a desiccator.

\subsection{Method comparison}

In order to compare the ex situ sampling methodology described above with the conventional in situ monitoring approach, additional instrumentation to measure $\mathrm{T}$ was in- 


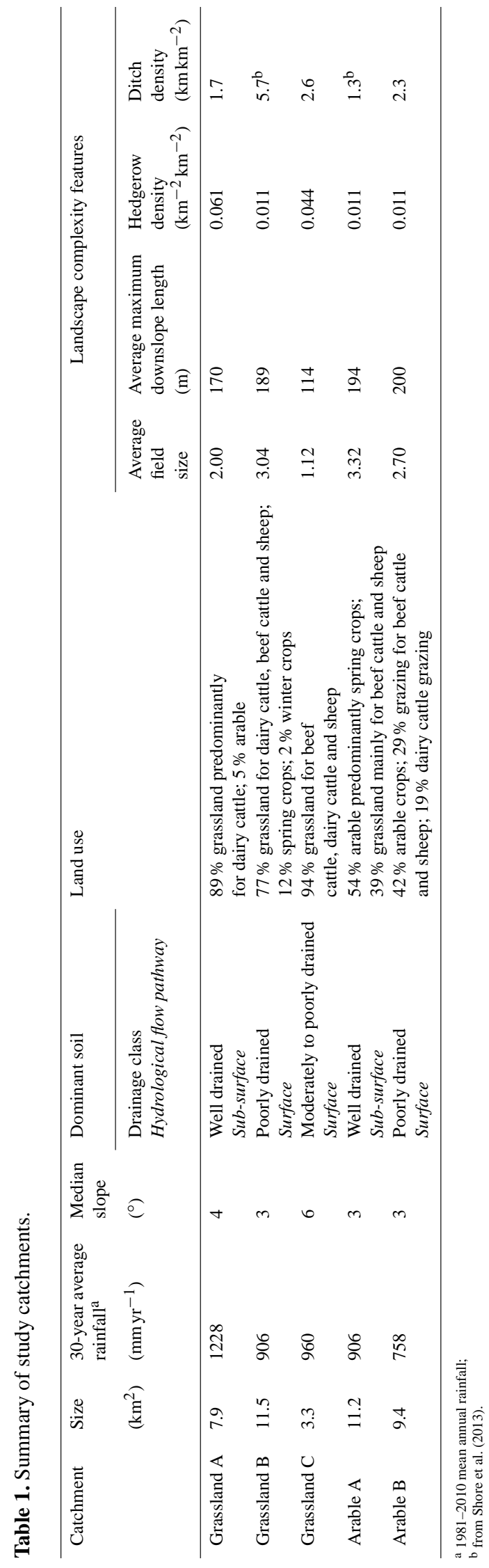

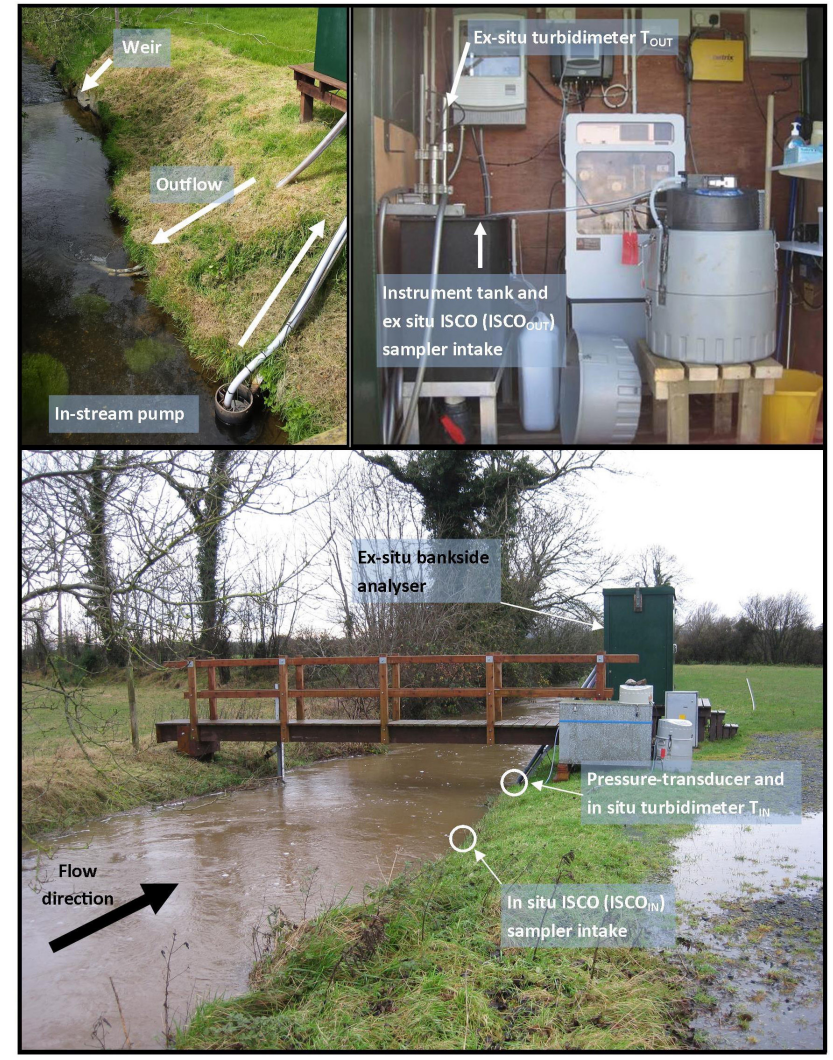

Figure 2. Picture of in situ and ex situ suspended sediment and discharge instrumentation at Grassland B.

stalled in Grassland B and Arable B from September to December 2012, and December 2012 to March 2013, respectively. A turbidimeter ( $\mathrm{T}_{\mathrm{IN}}$ ) (Analite, McVan, Australia, range $0-1000 \mathrm{NTU}$ ) fitted with a wiper blade to prevent biological fouling and automatic pumping sampler (ISCO IN) intake were positioned in situ, adjacent to the channel edge, in proximity to the bankside analyser pump intake $(1 \mathrm{~m}$ and $4 \mathrm{~m}$ upstream, respectively, in both catchments), but sufficiently distant not to affect, or to be affected by, the ex situ instrumentation. The turbidity sensor $\mathrm{T}_{\mathrm{IN}}$ and the ISCO IN $_{\text {Intake }}$ at Grassland B were approximately $20 \mathrm{~cm}$ above the channel bed and $15 \mathrm{~cm}$ from the bank edge. At Arable B, $\mathrm{T}_{\mathrm{IN}}$ and the ISCO IN intake were positioned approximately $10 \mathrm{~cm}$ from the bank edge and $10 \mathrm{~cm}$ above the channel bed. $T_{I N}$ and ISCO IN $_{\text {IN }}$ sample collection was synchronised to replicate the ex situ turbidity sensor ( $\mathrm{T}_{\text {OUT }}$ ) and pumping sampler (ISCO OUT) programme as described above. T-SSC rating curves were developed for each sensor using water samples collected at the respective positions (ISCO OUT and ISCO IN $_{\text {IN }}$ ) and applied to the raw turbidity set. Low-quality data capture attributed to spurious readings (a short-term increase in $\mathrm{T}$ output not associated with a known environmental process such as accompanying rise in $\mathrm{Q}$ or equipment maintenance) and saturation of the $T_{I N}$ sensor or missing data at 
Table 2. Turbidity-suspended sediment calibration data-set summary and rating curve equations and fit parameters.

\begin{tabular}{lllll}
\hline Catchment & Data points & $\begin{array}{l}\text { Calibrated turbidity } \\
\text { range (NTU) }\end{array}$ & $\begin{array}{l}\text { Maximum measured turbidity in NTU } \\
\text { (number of data points outside } \\
\text { calibrated range) }\end{array}$ & $\begin{array}{l}\text { Calibration } \\
\text { equation }\end{array}$ \\
\hline Grassland A & 247 & $0-725$ & $1074(n=7)$ & $\mathrm{SSC}=0.6636 \mathrm{~T}^{1.1045}$ \\
Grassland B & 443 & $1-577$ & $1179(n=37)$ & $\mathrm{SSC}=0.5657 \mathrm{~T}^{1.1109}$ \\
Grassland C & 339 & $1-154$ & $1225(n=207)$ & 580 \\
Arable A & 231 & $1-767$ & $2730(n=30)$ & $\mathrm{SSC}=0.4341 \mathrm{~T}^{1.2148}$ \\
Arable B & 242 & $1-1853$ & $1853(n=0)$ & $\mathrm{SSC}=0.4119 \mathrm{~T}^{1.1456}$ \\
& & & Where T $<432.2$ \\
& & & $\mathrm{SSC}=1.1320 \mathrm{~T}$ \\
& & & Where T $>432.2$ \\
& & & $\mathrm{SSC}=0.5288+0.6032 \mathrm{~T}$ \\
\hline
\end{tabular}

* Number of data points at $10 \mathrm{~min}$ resolution.

TOUT due to delivery system blockages did not undergo correction such that comparisons between methodologies could be made. Five storm-flow events were captured in Grassland $\mathrm{B}$ and two in Arable B for T-SSC calibration. Due to the location settings, the in situ automatic water sampler was fitted with a $7 \mathrm{~m}$ long intake tube in both catchments.

Depth-integrated water samples were manually collected $(n=171)$ from a bridge over each investigated channel during flood events, using a depth-integrating SS sampler (US DH-48, Rickly Hydrological; USA). These samples were used firstly to investigate the cross-sectional variability in sediment transportation, and secondly to provide a validation data set to assess and compare the efficacy of estimated SSC using in situ and ex situ T sensors. Samples were collected using two strategies: (1) depth-integrated samples taken at $20 \mathrm{~cm}$ intervals across the channel width in rapid succession, and (2) samples taken at coarser widths with roughly $1 \mathrm{~m}$ intervals. All samples were processed for SSC as described above. Due to the sampling approach used, consecutive depth-integrated samples reflected the event trend (either the rising or falling sedigraph limb) plus the cross-sectional trend. The event effect was de-trended using SSC estimated from the ex situ turbidimeter. The average change in SSC during transect sampling at $\mathrm{T}_{\text {OUT }}$, or the event trend, was $9 \%$ (range $1 \%$ at $175 \mathrm{mg} \mathrm{L}^{-1}$ to $19 \%$ at $442 \mathrm{mg} \mathrm{L}^{-1}$ ); the average transect time was $22 \mathrm{~min}$.

Where sufficient sample volume and sediment concentration existed, samples were analysed for particle size distribution using laser diffraction (Malvern Mastersizer 2000G, Malvern, UK). Samples were circulated for 2 min (pump speed $2000 \mathrm{rpm}$, stirrer speed $800 \mathrm{rpm}$ ) before analysis with no pre-treatment, i.e. physical or chemical dispersant, to broadly replicate the "effective particle size" measured by the turbidity sensor. To assess the effect of automatic sampler tube length, laboratory prepared SSC samples were collected using the two intake pump lengths $(1$ and $7 \mathrm{~m})$ used in-field. Ten $500 \mathrm{~mL}$ sub-samples (at 5, 10, 25, 50, 100, 250, 500, 750 and $1000 \mathrm{mg} \mathrm{L}^{-1}$ ) were collected from homogenised $10 \mathrm{~L}$ mixtures using each pump length and processed for SSC. A non-parametric Mann-Whitney $U$ test was conducted to compare SSC values collected at ISCO $_{\text {IN }}\left(\mathrm{SSC} \mathrm{ISCO}_{\mathrm{IN}}\right)$ and

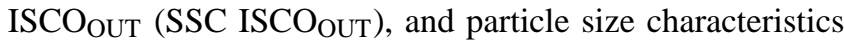
at the two study sites.

\subsection{Suspended sediment rating curve construction}

Data pairs for T-SSC calibration for each individual site (each catchment outlet over a complete time series) and method comparison investigations were statistically assessed using SAS 9.3 (SAS Institute Inc., USA). Two regression equations, power (Eq. 1) and two-section linear split at a threshold $\mathrm{T}^{\prime}$ (Eq. 2), were assessed using the mean square error (MSE) of the SSC predictions.

Power SSC $=a \mathrm{~T}^{b}$

Split linear SSC $=a \mathrm{~T}$ Where $\mathrm{T}<\mathrm{T}^{\prime}$

$\mathrm{SSC}=c\left(b_{1}-b_{2}\right)+b_{2} \mathrm{~T}$ Where $\mathrm{T}>\mathrm{T}^{\prime}$.

The intercept was set at zero for all regressions and was considered not to compromise fit at the upper end of the data set (cf. Thompson et al., 2014). Power relationships provided the best fit in Grassland A, Grassland B, Grassland C and Arable A, whereas the split linear relationship considerably improved fit at Arable B (Table 2). Using the selected curves, continuous turbidity measurements were computed to SSC and, using discharge data, were converted to instantaneous sediment load $\left(\mathrm{SSL}-\mathrm{t} \mathrm{s}^{-1}\right.$ ) and yield (SSY $-\mathrm{t} \mathrm{km}^{-2} \mathrm{yr}^{-1}$ ).

\section{Results and discussion}

\subsection{Method comparison}

Data-set completeness was similar in both $\mathrm{T}$ records (98$99 \%$ ); however, the timing and nature of spurious and/or missing $\mathrm{T}$ data were dissimilar (Fig. 3). Spurious data at $\mathrm{T}_{\mathrm{IN}}$ coincided with random peaks possibly relating to local debris interference around the sensor, which is a frequent problem 


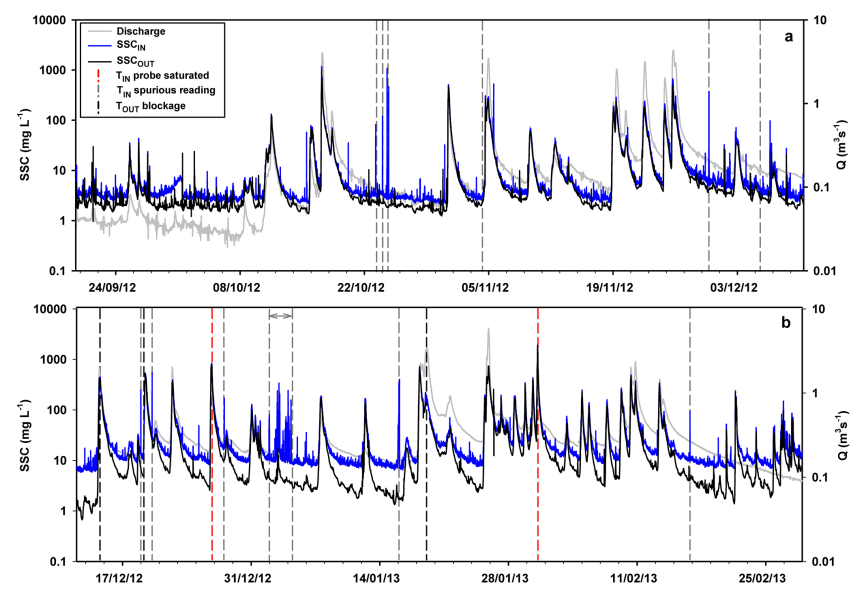

Figure 3. Raw turbidity output of $\mathrm{T}_{\mathrm{IN}}$ and $\mathrm{T}_{\mathrm{OUT}}$ sensors (converted to SSC) and discharge at (a) Grassland B and (b) Arable B. Periods of missing data are annotated by dashed lines.

in $\mathrm{T}$ analysis (Lewis and Eads, 2001). This effect was not recorded at $\mathrm{T}_{\text {OUT }}$, suggesting that the ex situ approach was less vulnerable to local in-stream debris interference (Jansson, 2002). Missing data at $\mathrm{T}_{\mathrm{IN}}$ during periods of high sediment concentration were attributed to sensor saturation at Arable B. The TouT probe estimated $5 \%$ of the total sediment load was delivered whilst $\mathrm{T}_{\mathrm{IN}}$ was saturated. Sporadically, pump blockages occurred in $\mathrm{T}_{\mathrm{OUT}}$ at Arable B due to extreme debris transport in the channel (Melland et al., $2012 b$ ); data collection was ordinarily restored in less than $2 \mathrm{~h}$. At $\mathrm{T}_{\mathrm{IN}} 6 \%$ of the total load was delivered during this period. The ex situ turbidity monitoring may be at greater risk of delivery system blockages, especially during key periods of elevated turbidity and sediment transfer. These short periods are critical for sediment transport as they are responsible for the majority of the annual sediment load (Walling and Webb, 1988; Lawler et al., 2006; Estrany et al., 2009; Navratil et al., 2011). Other key issues such as bio-fouling trends were not found in either data set, reflecting the subweekly frequency of maintenance at these sites.

Estimated sediment metrics (Table 3) during both monitoring periods showed discrepancies between the two measurement locations. Suspended sediment load estimated by ex situ equipment was $83 \%$ and $91 \%$ of in situ at Grassland B and Arable B, respectively, and mean SSC at SSC OUT was $85 \%$ of $\mathrm{SSC}_{\mathrm{IN}}$ at both locations. Differences in raw T output between the sensors were negated by calibration with SSC; however, the SSC of water samples from in situ (SSC

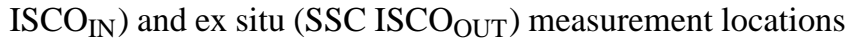
showed consistent differences. Samples at SSC ISCO OUT were 90 and $94 \%$ of SSC ISCO IN at Grassland B and Arable B catchments, respectively. The differences in SSC and loads between the two approaches were not statistically significant, as confirmed by the non-parametric Mann-Whitney $U$ test between SSC ISCO OUT and SSC ISCO IN $(p>0.05)$.

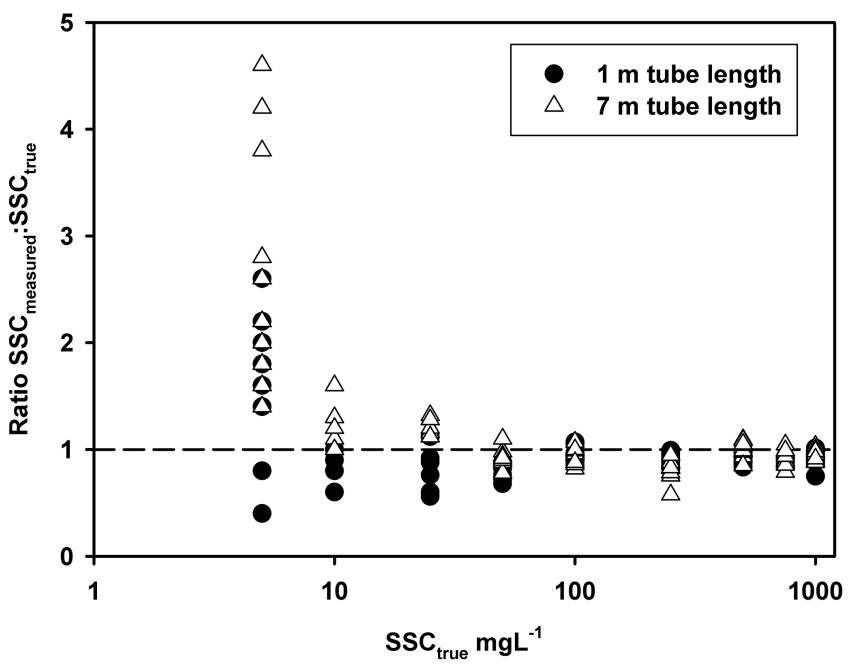

Figure 4. Suspended sediment concentration of samples collected from known concentration mixtures ( $\mathrm{SSC}_{\text {true }}$ ) using ISCO water samplers with 1 and $7 \mathrm{~m}$ tube lengths.

Particle size analysis of event samples showed that the proportion of silt and sand particles changed through the events, whereas clay remained consistent. The greater density of sand particles compared to silts and clays can impact SSC and be oversampled by pumped samples such as the ISCO IN $_{\text {IN }}$ approach (Horowitz, 2008). The percentage of sand (or sandsized aggregates) between SSC ISCO IN and SSC ISCOOUT did not differ significantly $(p>0.05)$. Additionally, the ratio of the sand-sized fraction between simultaneous samples

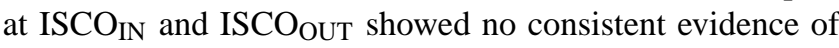
over- or under-collection by either collection method. The hypothesis that inadequate sample collection could affect the differences between SSCs at ISCO IN and ISCO $_{\text {OUT }}$ is unlikely, as contrasts between the sand-sized fractions seemed to be event specific.

Differences between SSC ISCO IN and SSC ISCOOUT could not be directly attributed to diverging particle size of the collected samples $(p>0.05)$, the pump length of the water sample collection ( $p>0.05$; Fig. 4 ), or the position of the sample intake within the cross section (Fig. 5). It is possible that the proximity of the ISCO IN $_{\text {IN }}$ pump intake to the channel bank could influence the relationship; however, differences could additionally result from methodological dissimilarities which could not be tested in isolation, i.e. the piped delivery of river water to the ex situ instrument tank. The impact of elevated SSCs from ISCO IN, compared to ISCO OUT on the calibration of turbidity sensors $\mathrm{T}_{\mathrm{IN}}$ and $\mathrm{T}_{\mathrm{OUT}}$, and the consequential prediction of high-resolution turbidity-based SSC record is discussed below.

\subsection{Method validation}

Samples collected from the channel cross section were used to test the accuracy of predicted SSC using calibrated tur- 
Table 3. Suspended sediment metrics estimated using in situ and ex situ turbidity-based SSC estimation methods.

\begin{tabular}{lllllll}
\hline \multirow{2}{*}{ Catchment } & \multicolumn{2}{c}{ Total load $(\mathrm{t})^{\mathrm{a}}$} & \multicolumn{2}{c}{ Mean concentration $\left(\mathrm{mg} \mathrm{L}^{-1}\right)$} & \multicolumn{2}{c}{ Max concentration $\left(\mathrm{mg} \mathrm{L}^{-1}\right)$} \\
\cline { 2 - 7 } & $\mathrm{SSL}_{\text {OUT }}$ & $\mathrm{SSL}_{\mathrm{IN}}$ & $\mathrm{SSC}_{\text {OUT }}$ & $\mathrm{SSC}_{\mathrm{IN}}$ & $\mathrm{SSC}_{\text {OUT }}$ & $\mathrm{SSC}_{\mathrm{IN}}$ \\
\hline Grassland B & $128 \pm 28$ & $154 \pm 35$ & 14 & 16 & 1010 & 1188 \\
Arable B & $225 \pm 54$ & $248 \pm 52$ & 29 & 34 & 2043 & $823^{\mathrm{b}}$ \\
\hline
\end{tabular}

${ }^{\text {a }}$ Confidence intervals are the coefficient of variance of the mean prediction.

b $\mathrm{T}_{\text {IN }}$ sensor saturated at 1000 NTU.
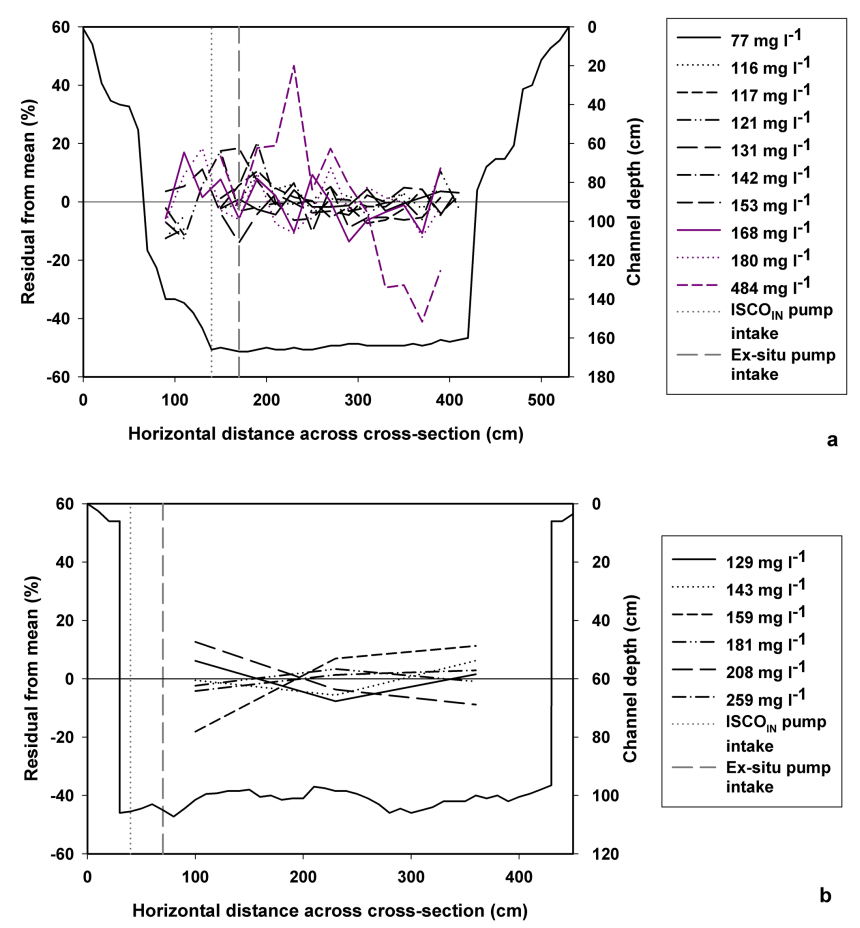

Figure 5. Variability of instantaneous depth-integrated SSC measurements across the channel cross section compared to the mean transect SSC using a US DH-48 sediment sampler at (a) Grassland $\mathrm{B}$ and (b) Arable B.

bidity sensors at in situ and ex situ locations. The average SSC from each cross-sectional, depth-integrated set of measurements was plotted onto the rating curve over the method comparison monitoring period (Fig. 6). At Grassland B, measured SSCs largely plot within the $95 \%$ confidence intervals of predicted SSC using both methodologies using the simultaneous $\mathrm{T}$ values. This trend is repeated for the majority of samples at Arable B; however, some data points plot outside of the $95 \%$ confidence intervals for both in situ and ex situ method data sets. In the case that these out of range values were consistently higher or lower than the predicted values, this may suggest a systematic error due to sampling strategy; however, both upper and lower confidence limits were exceeded by the SSC values (Fig. 6c and d). Therefore, the error associated with the measurement method was generally less than that encapsulated within the $95 \%$ prediction intervals of the T to SSC calibration curve and, consequently, both measurement approaches can be accepted as accurate for the estimation of SS metrics in these catchments. The suitability of ex situ water monitoring equipment installation must consider programme-specific research objectives. Melland et al. (2012b) stated that for policy evaluation studies including multiple water quality parameters in addition to SSC, the improved resolution, accuracy and precision, in particular for hydrologically dynamic catchments, justified the increased financial costs of initial installation of ex situ instrumentation.

\subsection{Suspended sediment metrics in five agricultural catchments}

High-magnitude SSCs were of short duration in all five catchments (e.g. Fig. 3 for Grassland B and Arable B), but such periods are typically critical to cumulative annual SSY (Fig. 7b - Walling and Webb, 1988; Navratil et al., 2011). Grassland B and Arable B had a large proportion (80\% of the monitoring period) of sediment transported at SSCs between 1 and $10 \mathrm{~m} \mathrm{~L}^{-1}$, and shorter periods of concentrations $\geq 10 \mathrm{mg} \mathrm{L}^{-1}$ for 15 and $20 \%$ of the monitoring period, respectively (Fig. 7). In the remaining catchments, low concentrations of $<1 \mathrm{mg} \mathrm{L}^{-1}$ were more common and occurred between 25 and $40 \%$ of the time. High concentrations $\left(\geq 10 \mathrm{mg} \mathrm{L}^{-1}\right)$ were limited to less than $10 \%$ of the monitoring period. Overall, however, the FFD average annual SSC guideline was not exceeded in any monitoring year in any of the catchments (Table 4). The highest mean SSCs were recorded at Grassland B (up to $14 \mathrm{mg} \mathrm{L}^{-1}$ ) and Arable $\mathrm{B}$ (up to $17 \mathrm{mg} \mathrm{L}^{-1}$ ) and the remaining catchments reported very low values of $<6 \mathrm{mg} \mathrm{L}^{-1}$. Accordingly, the instantaneous exceedance of the FFD guideline (Table 4) occurred during extremely short time periods $(1-11 \%$ of sampled time per year). The values here are similar to those reported by Thompson et al. (2014) in two other intensively managed grassland catchments in Ireland; $8 \%$ exceedance was reported in a moderately drained catchment in Co. Down and $18 \%$ exceedance in a poorly drained catchment in Co. Louth. Although the instantaneous exceedance of the FFD metric has been reported in other sediment studies (Glendell et al., 2014; Peukert et al., 2014; Thompson et al., 2014), 

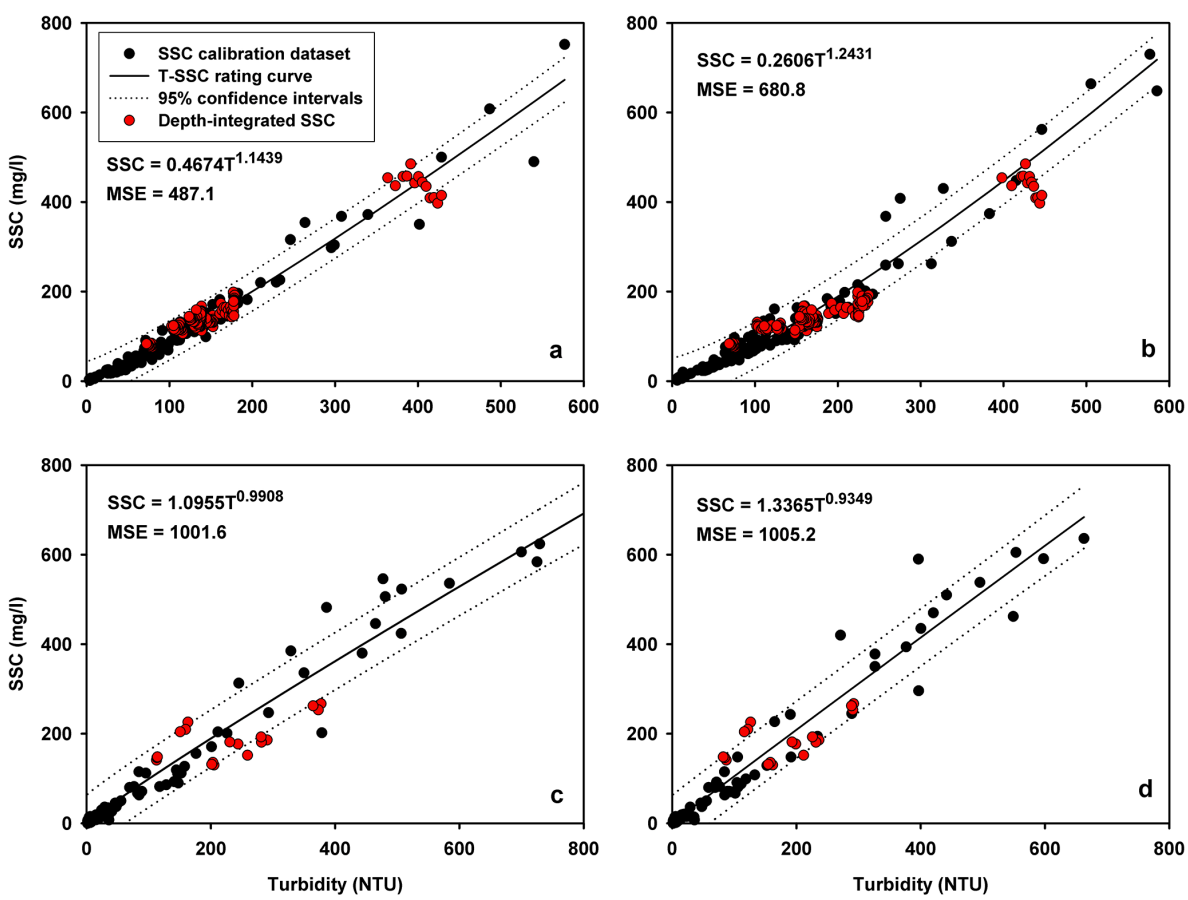

Figure 6. Turbidity-suspended sediment concentration rating curves, confidence intervals, calibration data and cross-sectional depthintegrated suspended sediment concentration samples for (a) Grassland B T $\mathrm{OUT}_{\mathrm{T}}$, (b) Grassland B TIN, (c) Arable B $\mathrm{T}_{\mathrm{OUT}}$, and (d) Arable B $\mathrm{T}_{\mathrm{IN}}$.

the transferability of this coarse threshold (compliance to which requires an undefined annual sample number) to highresolution SS data is questionable.

Average SSYs in the five catchments were 9, 25, 12, 12 and $24 \mathrm{t} \mathrm{km}^{-2} \mathrm{yr}^{-1}$ at Grassland A, Grassland B, Grassland C, Arable A and Arable B, respectively. Figure 8 illustrates average annual SSYs from Ireland, the United Kingdom (UK) and the wider Atlantic climatic region of Europe (Vanmaercke et al., 2011). The variability of average SSYs may be partly described by catchment size ( $x$ axis) but furthermore according to physical attributes such as soil type, which controls soil erodibility. Values from catchments assessed in this study align with existing data on SSY in Ireland (cf. Huang and O'Connell, 2000; Jordan et al., 2002; Harrington and Harrington, 2013; Thompson et al., 2014), and are consistently low compared with the UK and Europe. Considering the agricultural intensity of these catchments (for example, Grassland A is within the highest region of milk yield in Ireland; Läppe and Hennessy, 2012), and that crop yields across Ireland are internationally high (Melland et al., 2012a), these values are particularly low.

Catchment observations suggest high landscape complexity, comprising small and irregularly shaped fields, separated by a dense network of hedgerows and vegetated ditches (Table 1) reduced water and sediment connectivity potential between hillslopes and the channel network. Efficient drainage can be considered to reduce the spatial extent and temporal stability of connected areas and, considering the over- engineered nature of these ditch networks, encouraged sediment deposition (Shore et al., 2014). Furthermore, lower slope lengths reduce the hillslope erosion potential (Lal, 1988), and sediment trapping and soil erosion prevention by root binding of hedgerows were observed. However, at the catchment scale, greater efficiency of hillslope drainage can increase the erosivity of streams, in turn accelerating erosion from in-channel sources such as channel banks (Belmont et al., 2011; Massoudieh et al., 2013).

In the UK, Cooper et al. (2008) suggested annual average "target" and threshold "investigation" SSY values be based upon drainage class and catchment terrain characteristics. Grassland A and Arable A qualify as lowland well drained catchments and, on average, fall well below target and investigation SSY of 20 and $50 \mathrm{t} \mathrm{km}^{-2} \mathrm{yr}^{-1}$, respectively. Grassland B, Grassland C and Arable B, categorised as lowland predominantly poorly drained catchments, on average, fall below target and investigation thresholds of 40 and $70 \mathrm{t} \mathrm{km}^{-2}$ $\mathrm{yr}^{-1}$, respectively. Total SSY data for individual years (Table 4), however, indicate variability and exceeded respective SSY target values at Grassland B in 2009, Arable A in 2012 and Arable B in 2012.

Higher average SSC, intra-annual period of FFD exceedance, and average SSY in catchments Grassland B and Arable B are suggested to result from poorer soil drainage. During rainfall events, soils are rapidly saturated and critical overland flow pathways established, and consequently, eroded particles within these connected areas are transported 


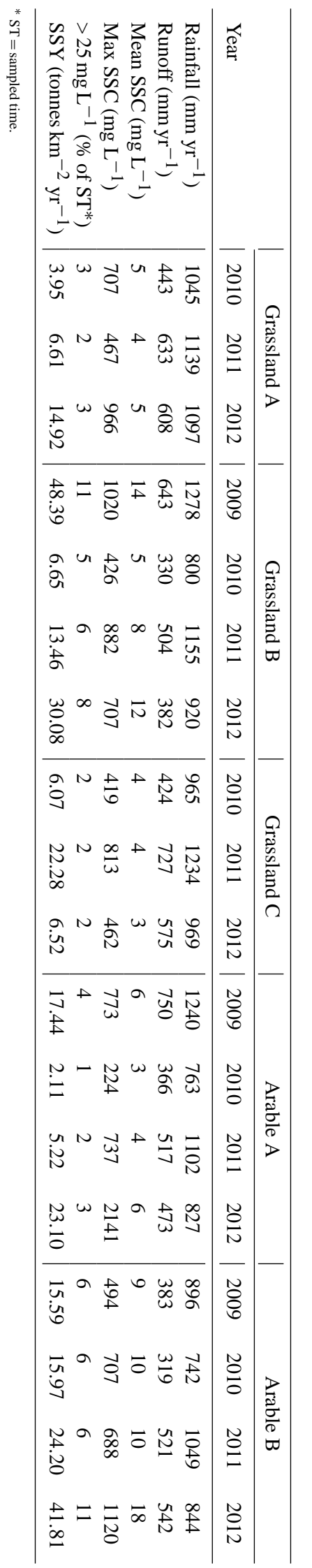

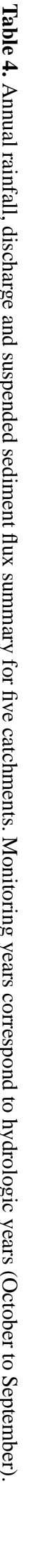
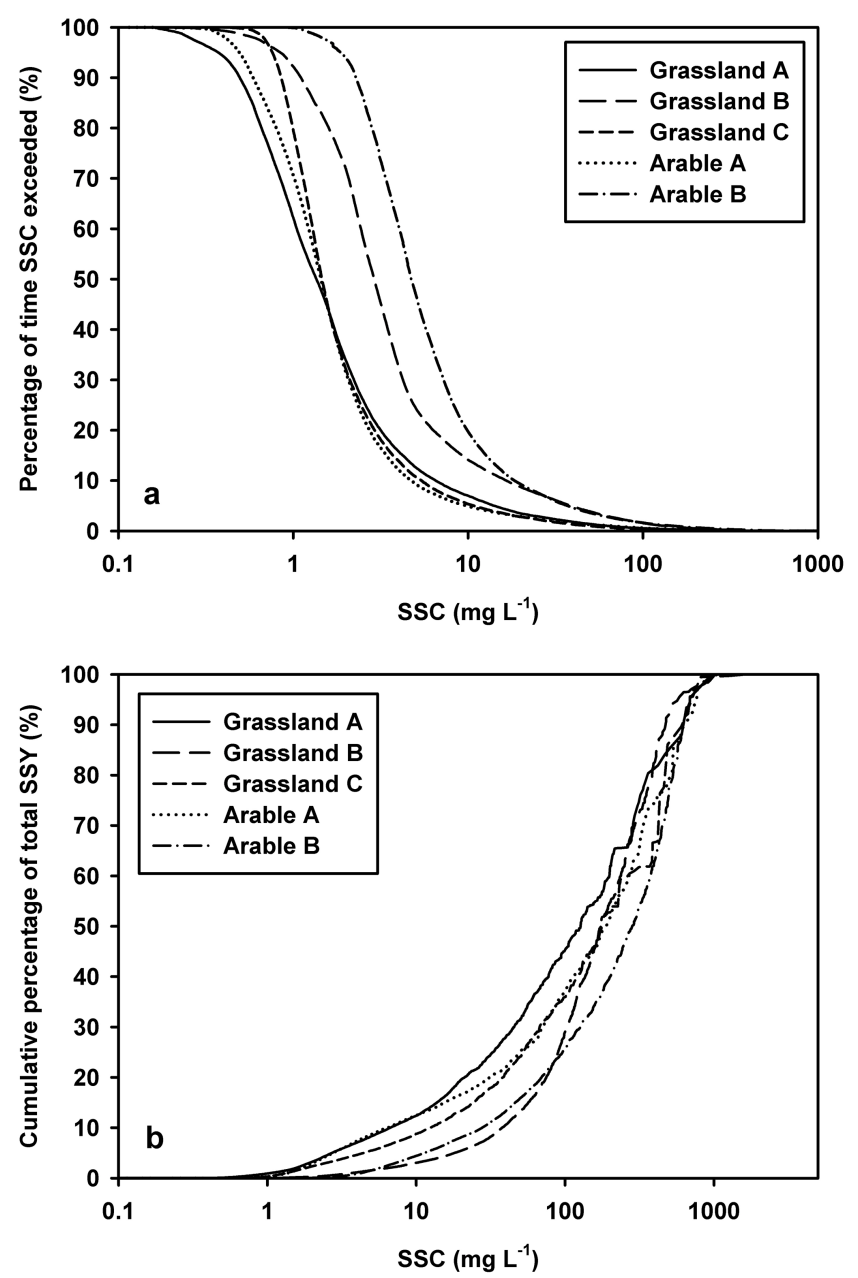

Figure 7. Frequency-duration graphs of (a) suspended sediment concentration exceedance with time and (b) cumulative percentage of suspended sediment yield with exceedance of suspended sediment concentration.

through the catchment (Mellander et al., 2012; Shore et al., 2013). The SSC responses here suggest, as in other catchments with impeded drainage, that high overland-flow potential is also associated with a notable proportion of sediment delivered at lower concentrations over a longer period, through surface and sub-surface flow pathways such as through macropores and tile drains (e.g. Deasy et al., 2009; Melland et al., 2012a; Ibrahaim et al., 2013; Mellander et al., 2015) resulting in increased average SSCs. In catchments Grassland A and Arable A, sub-surface flow pathways dominate, due to well drained soils reducing the likelihood of overland flow and consequently surface soil losses. Furthermore, at Arable A, Mellander et al. (2015) found that weathered bedrock formed groundwater pathways, further decreasing surface pathway initiation. Consequently, SSCs, the intra-annual period of FFD exceedance, and SSYs were low. Conversely, Grassland C more accurately reflects the sediment characteristics of the well drained catchments de- 


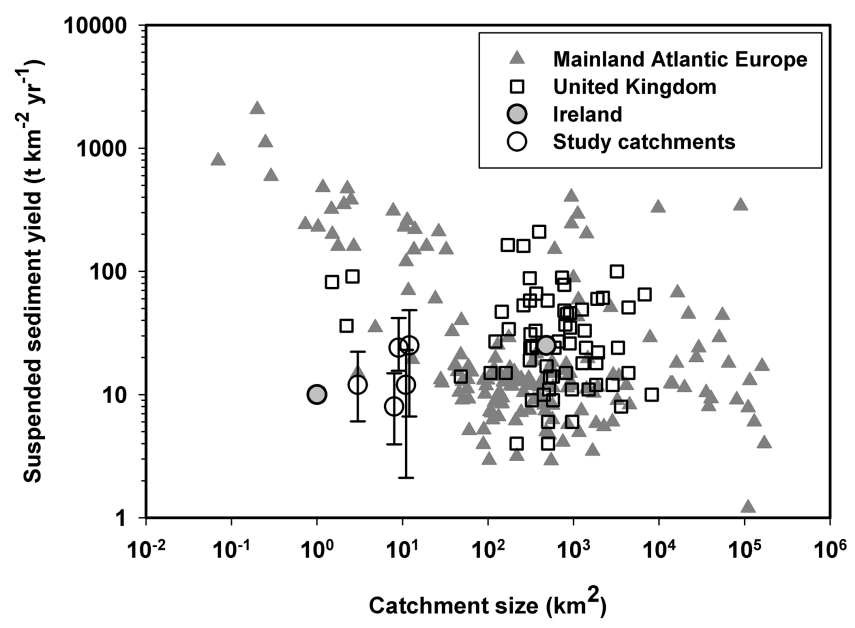

Figure 8. Catchment size and suspended sediment yield of European river catchments; study catchments displayed with interannual range. Sources: Foster et al. (1986); Milliman and Syvitski (1992); McManus and Duck (1996); Wass and Leeks (1999); Huang and O'Connell (2000); Verstraeten and Poesen (2001); Jordan et al. (2002); Walling et al. (2002); Harlow et al. (2006); Oeurng et al. (2010); Zabaleta et al. (2007); Gay et al. (2014).

spite the moderately to poorly drained soils. Near-complete cover of permanent pasture here was considered to sufficiently reduce sediment source availability and transport of sediment to the watercourse.

Generalisations can be made in relation to the overriding controls on SSY across the monitored catchments (Fig. 9). Inter-catchment comparisons here used data from hydrological years 2010 to 2013, where data were available for all five catchments. Sediment delivery was enhanced by the combined effect of an overland-flow dominated transport system (poorly drained soils) and, to a lesser extent, source availability (arable soils with potentially lengthy periods of bare ground cover (Regan et al., 2012) or seasonally thinly vegetated grassland soils; cf. Bilotta et al., 2010). Catchments that possess better drainage characteristics and/or permanent crop cover have greater resilience to extreme sediment losses. In catchments such as Arable A, where good drainage is combined with high source availability, the risk associated with sediment transport during extreme rainfall events and years was, nevertheless, high. Similarly, poorly drained soils stabilised by permanent pasture should be maintained and periods of bare cover should be avoided.

High inter-annual variability was evident, particularly with regard to SSY (Table 4). The annual SSY coefficients of variation (CV\%) were 67, 76, 79, 83 and $50 \%$ in Grassland A, Grassland B, Grassland C, Arable A and Arable B, respectively. Notably, in the Grassland B and Arable B catchments, the inter-annual SSY ranges of 42 and $26 \mathrm{t} \mathrm{km}^{-2} \mathrm{yr}^{-1}$, respectively, were greater than the average annual intercatchment SSY of approximately $24 \mathrm{t} \mathrm{km}^{-2} \mathrm{yr}^{-1}$ for both sites. The variability found within each of the five monitor-

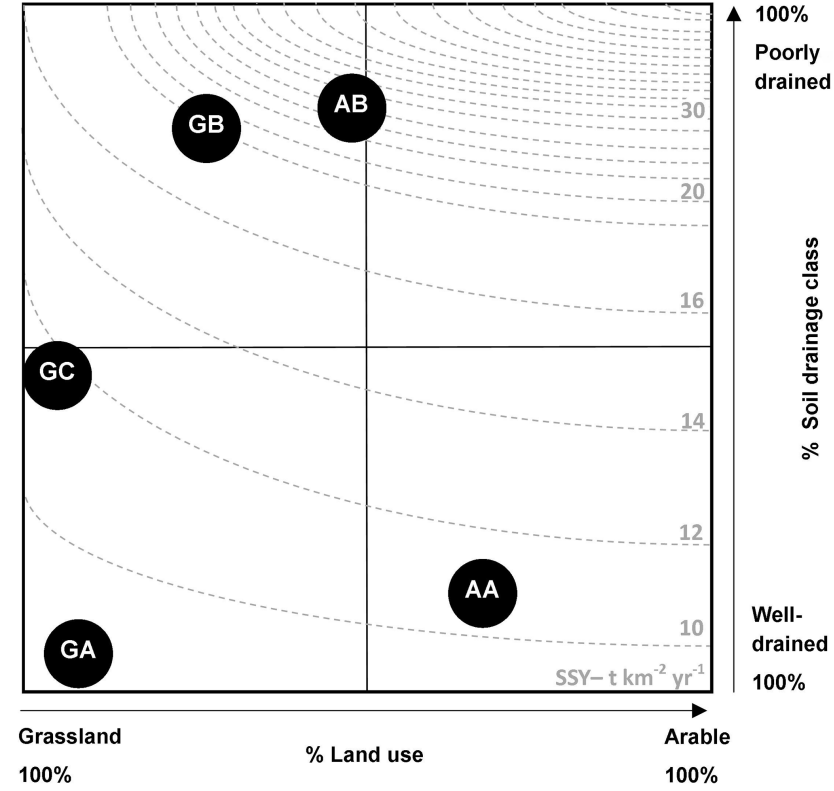

Figure 9. Conceptual diagram of suspended sediment yield as represented by iso-lines according to land use and dominant soil drainage class. Catchment abbreviations: GA - Grassland A; GB Grassland B; GC - Grassland C; AA - Arable A; AB - Arable B.

ing catchments was comparable to the results of Vanmaercke et al. (2012), who reported CV \% ranging from 6 to $313 \%$ (median $75 \%$ ) in 726 catchments worldwide. The catchment with the lowest inter-annual SSY $\left(11 \mathrm{t} \mathrm{km}^{-2} \mathrm{yr}^{-1}\right)$, Grassland $\mathrm{A}$, received the least variable rainfall input and total discharge.

Inter-annual SSY variability results from strong seasonality due to the timing and character of rainfall events, soil moisture deficit and land management which conditions sediment availability in critical source areas. Analysis of shorterterm sediment losses, i.e. at seasonal, monthly and event scales, would also provide empirical evidence to inform both high-level policy considerations and local decision making. Additionally, assessment of seasonal transfers are likely to have greater ecological significance as mean annual thresholds such as SSC (through the FFD), and SSY may underestimate the seasonal fluctuations of risk of sediments to aquatic ecosystems (Thompson et al., 2014). Sensitivity to sediment is species-specific and dependent upon life stage (Collins et al., 2011); therefore, shorter-term metrics such as the timing, magnitude, duration and frequency of sediment transfers are important concepts to consider. Existing static thresholds may, therefore, be considered ecologically irrelevant, particularly when utilised as an instantaneous threshold for highresolution data. Future discussion regarding sediment targets requires an assessment of multiple species and habitat quality. This task is particularly complicated where ecological condition is subject to multiple stressors such as nutrients (Bilotta and Brazier, 2008), bed substrate quality (Kemp et 
al., 2011) and time lag of water quality response to pollutant mitigation measures (Fenton et al., 2011; Vero et al., 2014).

Overall, annual average sediment metrics from small catchments $\left(\sim 10 \mathrm{~km}^{2}\right)$ with dominant land uses representative of main land use types in Ireland reported here are internationally low. Considering the spatial dominance and intensity of agricultural land use and high effective rainfall in the study catchments, this is perhaps unexpected, particularly considering the small scale of study. As previously discussed, the complexity of landscape features (e.g. fields, hedgerows, ditches) which are representative of the wider Irish agricultural landscape (Deverell et al., 2009) can be expected to decrease the likelihood of field-scale soil erosion, and/or increase the opportunity for interception and deposition of mobile particles on land or within the hydrological network. The Irish landscape may, therefore, improve the resilience of agricultural soils to soil loss. However, even with modest SSY, the potential for other specific risks to ecologically sensitive habitats, from SS deposition in rivers for example, will need a cautionary approach. Therefore, identification of the specific mechanisms promoting soil conservation or sediment retention in multiple catchments with contrasting physical and land use characteristics is important. This is particularly relevant for water and agricultural policy, as the prevention of environmental degradation and maintenance and/or sustainable intensification of agricultural production are simultaneously considered. Furthermore, other sediment sources, for example, from channel banks and road networks, may contribute significant proportions of the annual load (Rowan et al., 2012; Collins et al., 2013; Sherriff et al., 2014), particularly where strategies to reduce sediment loss on the hillslope scale such as sub-surface drainage may accelerate losses from channel sediment sources at the catchment scale. Assessment of such sources could be a useful insight to prioritise sediment management strategies (Wilson et al., 2008).

\section{Conclusions}

This study assessed the accuracy and reliability of an ex situ, turbidity-based methodology to estimate suspended sediment fluxes in multiple monitored catchments. Applying the method, annual SSC, FFD exceedance and SSY data in five catchments were further investigated in relation to physical catchment characteristics and land management. The key findings are:

- Suspended sediment metrics between in situ and ex situ methodologies were not significantly different from instream cross-sectional, depth-integrated samples in two monitoring catchments.
- The ex situ methodology reported less sensitivity to spurious data peaks; however, periods of extreme large debris transport increased the sensitivity of the ex situ instrumentation to short-term blockages.

- All catchments reported mean annual SSCs of less than the FFD threshold of $25 \mathrm{mg} \mathrm{L}^{-1}$ and short-term exceedance of $1-11 \%$ of sampled time.

- Inter-annual variability of SSY was strong due to the timing and character of rainfall events in relation to land management.

- Average annual SSYs in all five Irish catchments reported here were low in comparison to similar catchment and landscape settings elsewhere in Europe. Farming practices favouring relatively small fields, a high density of field boundaries including ditches, with low consequent connectivity are likely to explain this.

- Within the study catchments, SSY was higher in catchments dominated by poorly drained soils than those with well drained soils. Furthermore, on poorly drained soils, catchments with a greater proportion of arable land use reported the highest annual average SSY.

- Well drained soils dominated by arable crops did, however, show the potential to supply significant quantities of sediment.

- Complexity of landscape features (hedgerows, drainage ditches and irregular field sizes) may provide resilience to hillslope soil erosion and/or sediment transport despite spatial dominance and intensity of agriculture and these will be important considerations for future management (such as sustainable intensification) and/or SS mitigation in Ireland and elsewhere.

These findings illustrate that interactions between climate, landscape and land use regulate the supply of sediments from Irish agricultural catchments. Whilst the current SSYs are low by international standards, key questions still remain regarding the impact of land use on the magnitude and frequency characteristics of sediment transfers at shorter timescales. Seasonal and storm-event scale sediment transfers may better inform erosion risk due to better detection of sediment pulses moving into the channel network particularly within ecologically sensitive periods. Further to this, seasonal sediment provenance and field-scale soil loss assessments within this land management and landscape framework are crucial to quantify the contributions made from specific agricultural and other sediment sources. 
Acknowledgements. This study was funded by the Walsh Fellowship Programme, Teagasc, Ireland allied to the University of Dundee, UK, and the Teagasc Agricultural Catchments Programme (funded by the Department of Agriculture, Food and the Marine, Ireland). We thank Hugo McGrogan (Ulster University) for supplying and programming additional turbidity and pump-sampling equipment and Agricultural Catchments Programme colleagues for technical support. We finally acknowledge support from the farmers and landowners of the study catchments and two reviewers for comments on the manuscript.

Edited by: C. Stamm

\section{References}

Belmont, P., Gran, K. B., Schottler, S. P., Wilcock, P. R., Day, S. S., Jennings, C., Lauer, J. W., Viparelli, E., Willenbring, J. K., Engstrom, D. R., and Parker, G.: Large shift in source of fine sediment in the Upper Mississippi River, Environ. Sci. Technol., 45, 8804-8810, 2011.

Bilotta, G. S. and Brazier, R. E.: Understanding the influence of suspended solids on water quality and aquatic biota, Water Res., 42, 2849-2861, 2008.

Bilotta, G. S., Krueger, T., Brazier, R. E., Butler, P., Freer, J., Hawkins, J. M. B., Haygarth, P. M., Macleod, C. J. A., and Quinton, J. N.: Assessing catchment-scale erosion and yields of suspended solids from improved temperate grassland, J. Environ. Monit., 12, 731-739, 2010.

Boardman, J., Shepheard, M. L., Walker, E., and Foster, I. D. L.: Soil erosion and risk-assessment for on- and off-farm impacts: A test case using the Midhurst area, West Sussex, UK, J. Environ. Manage., 90, 2578-2588, 2009.

Borselli, L., Cassi, P., and Torri, D.: Prolegomena to sediment and flow connectivity in the landscape: A GIS and field numerical experiment, Catena, 75, 268-277, 2008.

Brils, J.: Sediment Monitoring and the European Water Framework Directive, Annali dell'Istituto Superiore di Sanita 44, 218-223, 2008.

Chambers, B. J., and Garwood, T. W. D.: Monitoring of water erosion on arable farms in England and Wales, 1990-1994, Soil Use Manag., 16, 93-99, 2000.

Collins, A. L. and Anthony, S. G.: Assessing the likelihood of catchments across England and Wales meeting 'good ecological status' due to sediment contributions from agricultural sources, Environ. Sci. Policy, 11, 163-170, 2008.

Collins, A. L., Naden, P. S., Sear, D. A., Jones, J. I., Foster, I. D. L., and Morrow, K.: Sediment targets for informing river catchment management: international experience and prospects, Hydrol. Process., 25, 2112-2129, 2011.

Collins, A. L., Williams, L. J., Zhang, Y. S., Marius, M., Dungait, J. A. J., Smallman, D. J., Dixon, E. R., Stringfellow, A., Sear, D. A., Jones, J. I., and Naden, P. S.: Catchment source contributions to the sediment-bound organic matter degrading salmonid spawning gravels in a lowland river, southern England, Sci. Total Environ., 456-457, 181-195, 2013.

Cooper, D., Naden, P., Old, G., and Laizé, C.: Development of guideline sediment targets to support management of sediment inputs into aquatic systems, Natural England Research Report NERR008, CEH Wallingford, 96 pp., 2008.

Deasy, C., Brazier, R. E., Heathwaite, A. L., and Hodgkinson, R.: Pathways of runoff and sediment transfer in small agricultural catchments, Hydrol. Process., 23, 1349-1358, 2009.

Deverell, R., McDonnell, K., and Devlin, G.: The impact of field size on the environment and energy crop production efficiency for a sustainable indigenous bioenergy supply chain in the Republic of Ireland, Sustainability, 1, 994-1011, 2009.

Duvert, C., Gratiot, N., Evrard, O., Navratil, O., Némery, J., Prat, C., and Esteves, M.: Drivers of erosion and suspended sediment transport in three headwater catchments of the Mexican Central Highlands, Geomorphology, 123, 243-256, 2010.

Estrany, J., Garcia, C., and Batalla, R. J.: Suspended sediment transport in a small Mediterranean agricultural catchment, Earth Surf. Process. Landf., 34, 929-940, 2009.

Evans, D. J., Gibson, C. E., and Rossell, R. S.: Sediment loads and sources in heavily modified Irish catchments: A move towards informed management strategies, Geomorphology, 79, 93-113, 2006.

Fealy, R. M., Buckley, C., Mechan, S., Melland, A. R., Mellander, P.-E., Shortle, G., Wall, D., and Jordan, P.: The Irish Agricultural Catchment Programme: catchment selection using spatial multicriteria decision analysis, Soil Use Manage., 26, 225-236, 2010.

Fenton, O., Schulte, R. P. O., Jordan, P., Lalor, S. T. J., and Richards, K. G.: Time lag: a methodology for estimation of vertical and horizontal travel and flushing timescales to nitrate threshold concentrations in Irish aquifers, Environ. Sci. Policy, 14, 419-431, 2011.

Florsheim, J. L., Pellerin, B. A., Oh, N. H., Ohara, N., Bachand, P. A. M., Bachand, S. M., Bergamaschi, B. A., Hernes, P. J., and Kavvas, M. L.: From deposition to erosion: Spatial and temporal variability of sediment sources, storage, and transport in a small agricultural watershed, Geomorphology, 132, 272-286, 2011.

Foster, I. D. L., Dearing, J. A., and Appleby, P. G.: Historical trends in catchment sediment yields: a case study from lake-sediment records in Warwickshire, UK, Hydrol. Sci. J., 31, 427-443, 1986.

Foster, I., Collins, A., Naden, P., Sear, D., Jones, J., and Zhang, Y. The potential for paleolimnology to determine historic sediment delivery to rivers, J. Paleolimnol., 45, 287-306, 2011.

Freebairn, D. M., Wockner, G. H., Hamilton, N. A., and Rowland, P.: Impact of soil conditions on hydrology and water quality for a brown clay in the north-eastern cereal zone of Australia, Aust. J. Soil Res., 47, 389-402, 2009.

Gay, A., Cerdan, O., Delmas, M., and Desmet, M.: Variability of suspended sediment yields within the Loire river basin (France), J. Hydrol., 519, 1225-1237, 2014.

Geraghty, M., Farrelly, I., Claringbold, K., Jordan, C., Meehan, R., and Hudson, M.: Geology of Monaghan-Carlingford. A geological description to accompany the Bedrock Geology 1:100,000 Scale Map Series, Sheet 8/9, Monaghan-Carlingford, Geological Survey of Ireland: Dublin, Ireland, 1997.

Glendell, M. and Brazier, R. E.: Accelerated export of sediment and carbon from a landscape under intensive agriculture, Sci. Total Environ., 476-477, 643-656, 2014.

Glendell, M., Extence, C., Chadd, R., and Brazier, R. E.: Testing the pressure-specific invertebrate index (PSI) as a tool for determining ecologically relevant targets for reducing sedimentation in streams, Freshwater Biol., 59, 353-367, 2014. 
Grangeon, T., Legout, C., Esteves, M., Gratiot, N., and Navratil, O.: Variability of the particle size of suspended sediment during highly concentrated flood events in a small mountainous catchment, J. Soils Sed., 12, 1549-1558, 2012.

Harlow, A., Webb, B. W., and Walling, D. E.: Sediment yields in the Exe Basin: a longer-term perspective, Sediment Dynamics and the Hydromorphology of Fluvial Systems, Dundee, UK, 12-20, 2006.

Harrington, S. T. and Harrington, J. R.: An assessment of the suspended sediment rating curve approach for load estimation on the Rivers Bandon and Owenabue, Ireland, Geomorphology, 185, 27-38, 2013.

Haygarth, P. M., Bilotta, G. S., Bol, R., Brazier, R. E., Butler, P. J., Freer, J., Gimbert, L. J., Granger, S. J., Krueger, T., Macleod, C. J. A., Naden, P., Old, G., Quinton, J. N., Smith, B., and Worsfold, P.: Processes affecting transfer of sediment and colloids, with associated phosphorus, from intensively farmed grasslands: an overview of key issues, Hydrol. Process., 20, 4407-4413, 2006.

Horowitz, A. J.: Determining annual suspended sediment and sediment-associated trace element and nutrient fluxes, Sci. Total Environ., 400, 315-343, 2008.

Huang, C. C. and O'Connell, M.: Recent land-use and soil-erosion history within a small catchment in Connemara, western Ireland: evidence from lake sediments and documentary sources, Catena, 41, 293-335, 2000.

Ibrahim, T. G., Fenton, O., Richards, K. G., Fealy, R. M., and Healy, M. G.: Spatial and temporal variations of nutrient loads in overland flow and subsurface drainage from a marginal land site in south-east Ireland, Biol. Environ., 113B, 169-186, 2013.

Jansson, M. B.: Determining sediment source areas in a tropical river basin, Costa Rica, Catena, 47, 63-84, 2002.

Jastram, J. D., Zipper, C. E., Zelazny, L. W., and Hyer, K. E.: Increasing Precision of Turbidity-Based Suspended Sediment Concentration and Load Estimates, J. Environ. Qual., 39, 1306-1316, 2010.

Jordan, P., Rippey, B., and John, A. N.: The 20th century wholebasin trophic history of an inter-drumlin lake in an agricultural catchment, Sci. Total Environ., 297, 161-173, 2002.

Jordan, P., Arnscheidt, A., McGrogan, H., and McCormick, S.: Characterising phosphorus transfers in rural catchments using a continuous bank-side analyser, Hydrol. Earth Syst. Sci., 11, 372381, doi:10.5194/hess-11-372-2007, 2007.

Jordan, P., Melland, A. R., Mellander, P. E., Shortle, G., and Wall, D.: The seasonality of phosphorus transfers from land to water: Implications for trophic impacts and policy evaluation, Sci. Total Environ., 434, 101-109, 2012.

Kemp, P., Sear, D., Collins, A., Naden, P., and Jones, I.: The impacts of fine sediment on riverine fish, Hydrol. Process., 25, 1800$1821,2011$.

Lal, R.: Effects of slope length, slope gradient, tillage methods and cropping systems on runoff and soil erosion on a tropical Alfisol: preliminary results, Proceedings of the Porto Alegre Symposium, December 1988, edited by: Bordas, M. P. and Walling, D. E., IAHS Publ., 174, 79-88, 1988.

Läppe, D. and Hennessy, T.: The capacity to expand milk production in Ireland following the removal of milk quotas, Irish J. Agr. Food Res., 51, 1-11, 2012.

Lawler, D. M., Petts, G. E., Foster, I. D. L., and Harper, S.: Turbidity dynamics during spring storm events in an urban headwater river system: The Upper Tame, West Midlands, UK, Sci. Total Environ., 360, 109-126, 2006.

Lewis, J.: Turbidity-controlled sampling for suspended sediment load estimation, edited by: Bogen, J., Fergus, T., and Walling, D. E., Proceedings of the Oslo Symposium, June 2002, IAHS Publication 337, 13-20, 2003.

Lewis, J., and Eads, R.: Turbidity threshold sampling for suspended sediment load estimation, in: Proceedings of the seventh federal interagency sedimentation conference, Technical committee of the subcommittee on sedimentation, Reno, 25-29 ${ }^{\text {th }}$ March 2001, 8 pp., 2001.

Massoudieh, A., Gellis, A., Banks, W. S., and Wieczorek, M. E.: Suspended sediment source apportionment in Chesapeake Bay watershed using Bayesian chemical mass balance receptor modeling, Hydrol. Process., 27, 3363-3374, 2013.

McManus, J. and Duck, R. W.: Regional variations of fluvial sediment yield in eastern Scotland, edited by: Walling, D. E. and Webb, B. W., Proceedings of the Exeter Symposium, July 1996, IAHS Publication 236, 157-161, 1996.

McConnell B., Philcox, M., and Geraghty, M..: Geology of Meath: A geological description to accompany the bedrock geology 1:100,000 scale map series, Sheet 13, Meath. Geological Survey of Ireland: Dublin, Ireland, 2001.

Melland, A. R., Mellander, P. E., Murphy, P. N. C., Wall, D. P., Mechan, S., Shine, O., Shortle, G., and Jordan, P.: Stream water quality in intensive cereal cropping catchments with regulated nutrient management, Environ. Sci. Policy, 24, 58-70, 2012a.

Melland, A. R., Ryan, D., Shortle, G., and Jordan, P.: A cost:benefit evaluation of in-situ high temporal resolution stream nutrient monitoring, World Congress on Water, Climate and Energy, Dublin, 13-18 May 2012b.

Mellander, P.-E., Melland, A. R., Jordan, P., Wall, D. P., Murphy, P. N. C., and Shortle, G.: Quantifying nutrient transfer pathways in agricultural catchments using high temporal resolution data, Environ. Sci. Policy, 24, 44-57, 2012.

Mellander, P.-E., Melland, A. R., Murphy, P. N. C., Wall, D. P., Shortle, G., and Jordan, P.: Coupling of surface water and groundwater nitrate- $\mathrm{N}$ dynamics in two permeable agricultural catchments, J. Agr. Sci., 152, 107-124, 2014.

Milliman, J. D. and Syvitski, J. P. M.: Geomorphic/Tectonic control of sediment discharge to the ocean: the importance of small mountainous rivers, J. Geol., 100, 525-544, 1992.

Navratil, O., Esteves, M., Legout, C., Gratiot, N., Nemery, J., Willmore, S., and Grangeon, T.: Global uncertainty analysis of suspended sediment monitoring using turbidimeter in a small mountainous river catchment, J. Hydrol., 398, 246-259, 2011.

Oeurng, C., Sauvage, S., and Sánchez-Pérez, J.-M.: Dynamics of suspended sediment transport and yield in a large agricultural catchment, southwest France, Earth Surf. Process. Landf., 35, 1289-1301, 2010.

OJEU: Council Directive 91/676/EEC of 12 December 1991 concerning the protection of waters against pollution caused by nitrates from agricultural sources, EU, Brussels, 1991.

OJEU: Establishing a Framework for Community Action in the Field of Water Policy (Water Framework Directive), 2000/60/EC, EU, Brussels, 2000

OJEU: Council Directive 2006/44/EC of the 6 September 2006 on the quality of fresh waters needing protection or improvement in order to support fish life, EU, Brussels, 2006. 
OJEU: Commission Decision 2007/697/EC of 22 October 2007 granting a derogation requested by Ireland pursuant to Council Directive 91/676/EEC concerning the protection of water against pollution caused by nitrates from agricultural sources, EU, Brussels, 2007.

Owen, G. J., Perks, M. T., Benskin, C. M. H., Wilkinson, M. E., Jonczyk, J., and Quinn, P. F.: Monitoring agricultural diffuse pollution through a dense monitoring network in the River Eden Demonstration Test Catchment, Cumbria, UK, Area, 44, 443453, 2012.

Peukert, S., Griffith, B. A., Murray, P. J., Macleod, C. J. A., and Brazier, R. E.: Intensive Management in Grasslands Causes Diffuse Water Pollution at the Farm Scale, J. Environ. Qual., 43, 2009-2023, 2014.

Regan, J. T., Fenton, O., and Healy, M. G.: A review of phosphorus and sediment release from Irish tillage soils, the methods used to quantify losses and the current state of mitigation practice, Biol. Environ., 112B, 1-25, 2012.

Rowan, J. S., Black, S., and Franks, S. W.: Sediment fingerprinting as an environmental forensics tool explaining cyanobacteria blooms in lakes, Appl. Geogr., 32, 832-843, 2012.

Sherriff, S. C., Rowan, J. R., Franks, S. W., Walden, J., Melland, A. R., Jordan, P., and ÓhUallacháin, D.: Sediment Fingerprinting, TResearch, Summer 2014, 40-41, 2014.

Shore, M., Murphy, P. N. C., Jordan, P., Mellander, P. E., KellyQuinn, M., Cushen, M., Mechan, S., Shine, O., and Melland, A. R.: Evaluation of a surface hydrological connectivity index in agricultural catchments, Environ. Model. Softw., 47, 7-15, 2013.

Shore, M., Jordan, P., Mellander, P.-E., Kelly-Quinn, M., and Melland, A. R.: An agricultural drainage channel classification system for phosphorus management, Agr. Ecosystems Environ., 199, 207-215, 2014.

Silgram, M., Jackson, D. R., Bailey, A., Quinton, J., and Stevens, C.: Hillslope scale surface runoff, sediment and nutrient losses associated with tramline wheelings, Earth Surf. Process. Landf., 35, 699-706, 2010.

Sleeman, A. G. and Pracht, M.: Geology of South Cork, Sheet 25, Geological Survey of Ireland: Dublin, Ireland, 1995.

Soane, B. D., Ball, B. C., Arvidsson, J., Basch, G., Moreno, F., and Roger-Estrade, J.: No-till in northern, western and south-western Europe: A review of problems and opportunities for crop production and the environment, Soil Till. Res., 118, 66-87, 2012.

Thompson, J., Cassidy, R., Doody, D. G., and Flynn, R.: Assessing suspended sediment dynamics in relation to ecological thresholds and sampling strategies in two Irish headwater catchments, Sci. Total Environ., 468-469, 345-357, 2014.

Tietzsch-Tyler, D., Sleeman, A. G., McConnell, B. J., Daly, E. P., Flegg A. M., O'Connor P. J., and Warren W. P.: Geology of Carlow-Wexford, Sheet 19. Geological Survey of Ireland: Dublin, Ireland, 1994.

Trimble, S. W. and Mendel, A. C.: The cow as a geomorphic agent - A critical review, Geomorphol., 13, 233-253, 1995.
Van Oost, K., Cerdan, O., and Quine, T. A.: Accelerated sediment fluxes by water and tillage erosion on European agricultural land, Earth Surf. Process. Landf., 34, 1625-1634, 2009.

Vanmaercke, M., Poesen, J., Verstraeten, G., de Vente, J., and Ocakoglu, F.: Sediment yield in Europe: Spatial patterns and scale dependency, Geomorphol., 130, 142-161, 2011.

Vanmaercke, M., Poesen, J., Radoane, M., Govers, G., Ocakoglu, F., and Arabkhedri, M.: How long should we measure? An exploration of factors controlling the inter-annual variation of catchment sediment yield, J. Soils Sed., 12, 603-619, 2012.

Vero, S. E., Ibrahim, T. G., Creamer, R. E., Grant, J., Healy, M. G., Henry, T., Kramers, G., Richards, K. G., and Fenton, O.: Consequences of varied soil hydraulic and meteorological complexity on unsaturated zone time lag estimates, J. Contam. Hydrol., 170, 53-67, 2014.

Verstraeten, G. and Poesen, J.: Factors controlling sediment yield from small intensively cultivated catchments in a temperate humid climate, Geomorphology, 40, 123-144, 2001.

Wall, D., Jordan, P., Melland, A. R., Mellander, P. E., Buckley, C., Reaney, S. M., and Shortle, G.: Using the nutrient transfer continuum concept to evaluate the European Union Nitrates Directive National Action Programme, Env. Sci. Policy, 14, 664-674, 2011.

Walling, D. E.: Tracing suspended sediment sources in catchments and river systems, Sci. Total Environ., 344, 159-184, 2005.

Walling, D. E. and Webb, B. W.: The reliability of rating curve estimates of suspended sediment yield: some further comments, Sediment budgets, Porto Alegre, 337-350, 1988.

Walling, D. E., Owens, P. N., and Leeks, G. J. L.: Fingerprinting suspended sediment sources in the catchment of the River Ouse, Yorkshire, UK, Hydrol. Process., 13, 955-975, 1999.

Walling, D. E., Russell, M. A., Hodgkinson, R. A., and Zhang, Y.: Establishing sediment budgets for two small lowland agricultural catchments in the UK, Catena, 47, 323-353, 2002.

Wass, P. D. and Leeks, G. J. L.: Suspended sediment fluxes in the Humber catchment, UK, Hydrol. Process., 13, 935-953, 1999.

Wilson, C. G., Kuhnle, R. A., Bosch, D. D., Steiner, J. L., Starks, P. J., Tomer, M. D., and Wilson, G. V.: Quantifying relative contributions from sediment sources in Conservation Effects Assessment Project watersheds, J. Soil Water Conserv, 63, 523-532, 2008.

Wiskow, E. and van der Ploeg, R. R.: Calculation of drain spacings for optimal rainstorm flood control, J. Hydrol., 272, 163-174, 2003.

Withers, P. J. A., Hodgkinson, R. A., Bates, A., and Withers, C. M.: Some effects of tramlines on surface runoff, sediment and phosphorus mobilization on an erosion-prone soil, Soil Use Manage., 22, 245-255, 2006.

Wood, P. J. and Armitage, P. D.: Biological effects of fine sediment in the lotic environment, Environ. Manage., 21, 203-217, 1997.

Zabaleta, A., Martínez, M., Uriarte, J. A., and Antigüedad, I.: Factors controlling suspended sediment yield during runoff events in small headwater catchments of the Basque Country, Catena, 71, 179-190, 2007. 